\title{
MEMOIR
}

\section{VICTOR THOMPSON}

VIC Thompson was born in September 1910 in Norsewood, New Zealand and was sent to boarding school where he performed well becoming Dux and Head Prefect.

In 1929 Vic joined the Lands and Survey Department as a cadet and studied part-time at university. He did so well, particularly in mathematics, that he was transferred to the Government Actuary's Office in 1932.

He qualified as a Fellow of the Institute in 1942 and in 1959 was appointed New Zealand Government Actuary, Actuary to the Government Life Insurance Office and Registrar of Friendly Societies. In 1965 he was appointed Registrar of Building Societies and he held all these appointments until his retirement in September 1970.

In all these capacities and through all the changes in conditions over many years Vic took a broad view and saw the institutions in their social context. His wide social and historical perspective was demonstrated in a paper of which he was principal author on the subject of Social Security in New Zealand, presented to the Institute of Actuaries of Australia and New Zealand in 1971.

Vic was always interested in professional matters and, as Institute representative, advised a generation of prospective students and took a particular interest in supporting and guiding those who joined the Government Actuary's Office. His vigorous personality had a major effect on the development of the actuarial profession and the life insurance industry in New Zealand.

In retirement Vic maintained an interest in professional matters and continued to surprise those still involved on a day-to-day basis. not just with his knowledge of current developments, but also with his clarity of mind and freshness of view:

His sudden illness and death on 16 October 1989 was a great shock to his family and his many friends.

R. A. Jessup 